\title{
THE FOREIGN POLICY OF MODERN JAPAN
}


This volume is one of a series on Japanese society published by the University of California Press under a special arrangement with the Social Science Research Council. Each volume is based upon a conference attended by Japanese and foreign scholars; the purpose of each conference was to increase scholarly knowledge of Japanese society by enabling Japanese and foreign scholars to collaborate and to criticize each other's work. The conferences were sponsored by the Joint Committee on Japanese Studies of the American Council of Learned Societies and the Social Science Research Council, with funds provided by the Ford

Foundation. 


\title{
THE FOREIGN POLICY OF MODERN JAPAN
}

\author{
Edited by \\ Robert A. Scalapino
}

Foreword by

Edwin O. Reischauer

UNIVERSITY OF CALIFORNIA PRESS

Berkeley · Los Angeles · London 
University of California Press

Berkeley and Los Angeles, California

University of California Press, Ltd.

London, England

Copyright $\odot 1977$ by

The Regents of the University of California

ISBN 0-520-03499-6

Library of Congress Catalog Card Number: 75-15219

Printed in the United States of America 